\title{
Ecological Modernization Theory and Domestic Consumption
}

\section{GERT SPAARGAREN*}

Environmental Policy Group, Wageningen University, Wageningen, The Netherlands

\begin{abstract}
In the first part of the paper, the theory of ecological modernization is discussed with respect to some of its central assumptions, taking into account a number of the criticisms that have been raised against the theory. It is argued that the focus of the theory on substance and energy flows within social systems does not necessarily imply a resort to some sort of 'naïve realism' which denies the inherently social and contested nature of environmental problems. It is, however, important for environmental sociologists to take on board indicators and criteria that refer to the material dimension of social systems in order to be able to contribute to the debate on sustainable production and consumption. Furthermore, it is argued that environmental technologies are of crucial importance for bringing about more sustainable ways of industrial production and consumption. It is described how the real or supposed dangers of a central focus on technology would result in a technological-fix scheme of environmental social change, or a shallow form of green capitalism. We conclude the section on the general characteristics of the theory with a plea for elaborating ecological modernization theory at the middle-range level, taking into account the different social and environmental characteristics of the various 'target groups' that figure as the central objects of environmental policy-making. The second part of the paper takes the target group of domestic consumers as a point of departure for elaborating ecological modernization theory. Structuration theory is applied to design a model which can be used as an analytical tool in investigating the ecological modernization of domestic consumption. The EU-funded international DOMUS project is used to illustrate the need for consumer involvement in the ecological modernization of domestic routines and life-styles. The paper concludes with a short discussion of the political questions that go along with eco-modernization of domestic consumption under conditions of reflexive modernity. Copyright (C) 2000 John Wiley \& Sons, Ltd.
\end{abstract}

Key words: ecological modernization; domestic consumption; social theory; life-style

\section{Introduction}

Ecological modernization theory has become one of the leading perspectives in environmental sociology. As a sociological theory, it is broader in definition than, for example, political sciences, including the role of (civil society) actors in bringing about environment-induced social change. During the past decade, we have been developing the ecological modernization approach on both formal and substantial levels. Formally, the ecological modernization approach is situated within general sociology and the environmental sciences, including, of course, environmental sociology (Buttel, 2000; Mol \& Spaargaren, 2000; Spaargaren, 2000; Spaargaren et al., 2000). Situating it within such theoretical

* Correspondence to: Environmental Policy Group, Wageningen University, Hollandseweg 1, NL-6706 KN Wageningen, The Netherlands. Tel: + $31317483874_{i}$ fax: + $31317483990 ;$ e-mail: gert.spaargaren@alg.swg.wau.nl

Copyright (C) 2000 John Wiley \& Sons, Ltd. discourses allows for the confrontation with assumptions embraced by the demodernization theories of the 1970s (Schumacher, 1973; Ullrich, 1979), neo-Marxist approaches of the 1970s and 1980s (Schnaiberg, 1980) and the constructivist approaches if the 1980s and 1990s (Yearley, 1991; Hannigan, 1995; Blühdorn, 2000). These confrontations highlighted specific aspects of the ecological modernization approach and contributed to this evolving theory from its initial formulations to its present shape. Elsewhere, we provided an overview of the ways in which ecological modernization theory has been developed over the past 20 years (Mol \& Spaargaren, 2000). The aim of this contribution is not to jump into the theoretical assumptions and controversies, but rather to point out a few crucial and, at the same time, disputed elements of the theory (section 'Some basic characteristcs of ecological modernization theory'). An important part of the paper will be 
on one particular discussion and illustration of ecological modernization theory, looking at the role of citizen-consumers in bringing about more sustainable ways of domestic consumption (section 'A consumer-led perspective on ecological modernization: the example of domestic consumption'). The paper concludes with some questions on the politics of the ecological modernization of everyday life (section 'Intermezzo: empirical research on ecological modernization of domestic consumption in some European countries').

\section{Some basic characteristics of ecological modernization theory}

One of the confrontations that ecological modernization theory has deliberately sought has been with ecology, biology and the natural sciences. The premise of this contention is based upon the conviction that the environmental crisis is a 'real' crisis, dealing with real, objective, physical properties of social systems. In this sense, physical properties that have been changing over time confront us with a challenge that has to be taken seriously in order to avoid distorted social reproduction. This objectivist or realist position of ecological modernization theory has resulted in some severe criticisms, and significant disagreement from some (strong) constructivists (Blühdorn, 2000). With respect to the 'realism' associated with ecological modernization theory, we want to point out that ecological modernization theory is not the specific realm of naïve technical scientists believing that the environmental crisis can be reduced to (undisputed) physical properties and their technical engineering. Instead, the approaches of environmental scientists and policymakers who work with substance and energy flows-related definitions of the environment in a too narrow or restricted way are precisely the approaches being challenged. By taking substance flows into consideration from a sociological point of view, the objective is to bridge the gap between the technical and social environmental sciences. This is not an easy task, given the gulf between oversocialized constructivists

Copyright (c) 2000 John Wiley \& Sons, Ltd. and undersocialized environmental (e.g. climate change) experts and policy-makers, who tend to overlook the fact that there are people, social systems and human behaviours attached to changing substance flows. Ecological modernization theory, as developed by sociologists, stresses the fact that the environmental crisis is a thoroughly social crisis in terms of a series of problems in the way we deal with the sustenance base. These problems, it is argued, are not incidental or ad boc in character, but stem from a 'structural design fault' (Giddens, 1990, pp. 151-152) in the organization of production and consumption in modern societies.

Ecological modernization theory focuses on the ways in which substance flows management can and 'should' be organized in modern societies in a more appropriate way, arguing that such management or control pertains both to technological and social devices and mechanisms. The fact that science and technology (both in hardware and software dimensions) receive a prominent position within ecological modernization theory has triggered some lasting misinterpretations, which sometimes result in the ecological modernization approach characterized as technocratic or as a technological-fix approach. Indeed, environmental reform in the ecological modernization school would mean resorting to the ultimate power of new technologies that 'solve' environmental problems without any real or profound social changes (Hannigan, 1995, p. 184). The probable root of this misunderstanding is that environmental technology plays an important role within ecological modernization theory. The development from (compartmentally organized) end-of-pipe technologies in the early 1970 s to ('integrated') preventive technologies in the late 1980s, is, in fact, one of the key elements of ecological modernization theory, because these latter technologies are of crucial importance for what Huber (1985, p. 20) refers to as the 'switch-over' into a more sustainable modernity. In the technological-fix criticism, it is also implicitly or explicitly argued that ecological modernization theory lacks the 'radicalism' that characterizes demodernization and 'treadmill' perspectives on environmental change, and leads to an association that calls for 'green capitalism' (Martell,

J. Environ. Policy Plann. 2: 323-335 (2000) 
1994, p. 72). This is understandable to some extent, given that ecological modernization theory does not plead for a dismantling of 'capitalism' altogether. Instead, it focuses on the industrial modes of production and consumption, regarding this cluster of institutions as the main cause of environmental problems. Taking on board issues like innovation, diffusion of new technologies or management techniques, as applied in industrial organizations, it deals with themes like Fordist versus post-Fordist production regimes and their implications for the environment. In that sense, ecological modernization theory can be situated in the stream of thought that is often referred to as industrial society theory.

Compared with treadmill analyses (Schnaiberg, 1980; Pellow et al., 2000) or demodernization perspectives (Ullrich, 1979), ecological modernization theory is indeed less 'radical', largely because it does not start from the a priori assumption that a more sustainable organization of production and consumption in modern societies is impossible because of their capitalist character. It also does not oppose 'growth' in all respects and on all occasions. In these respects, ecological modernization theory resembles some of the major assumptions of the Brundtland report, although it is more precise in developing criteria or sets of criteria that can and should be used to make judgements on the sustainability of production and consumption cycles.

Reflection on the basic characteristics and possible (theoretical and political) uses of these criteria is one of the prime occupations of ecological modernization theory. During the past two decades, sets of criteria have been developed that allow for a discussion, within governmental and academic circles, on the ecological rationality of certain technologies, production arrangements and even complete sectors of (chemical) industry. These ecological criteria have been and still are gaining (albeit slowly and gradually) an 'independent' existence in the sense that they can no longer be reduced to economic or political criteria alone. On the level of formal theory, one can conceive of this fact in terms of a separate sphere that comes to exist alongside the spheres of the economy, culture and politics, as Figure 1 illustrates.

Copyright (C) 2000 John Wiley \& Sons, Ltd.

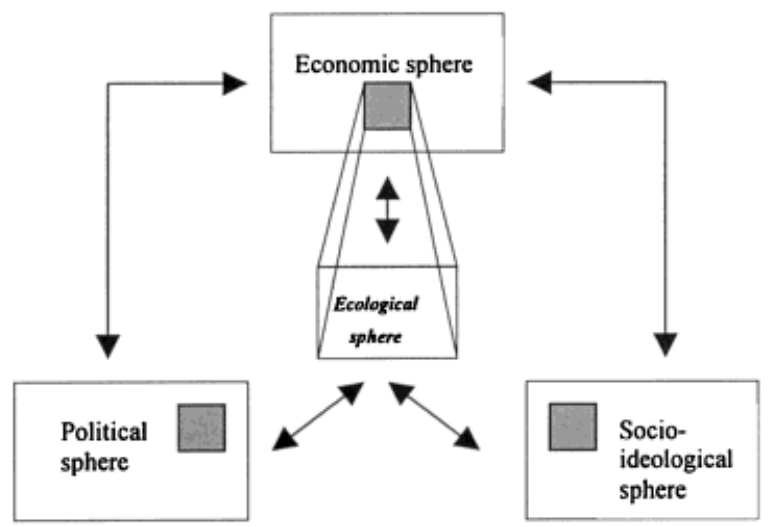

Figure 1. Growing independence of the ecological sphere.

It is important to note that fashionable concepts, such as pollution prevention pays (PPP), win-win, or Dopple Nutzung are not the kernel of this approach, as is often claimed in (business) circles that reduce ecological modernization simply to an 'efficiency revolution' (see the contribution by Huber to this issue). Such 'fashionable concepts' are significant, however, in highlighting the existence of new principles that can be added to basic understandings of what a more sustainable way of organizing industrial production and consumption might look like. Principles of recycling, prevention, green gross national product, energy extensification and the use of sustainable energy sources are today elements of everyday (business) discourse. What is essential is not the fact that the greening of production can bring about profits (one aspect always highlighted by certain interest groups), but the fact that it will, eventually and inevitably, result in a process of monitoring and 'guarding' of all the major substance and energy flows. Instruments such as life cycle analyses (LCA), environmental performance indicators and the use of all kinds of environmental quality norms (e.g. International Standards Organization (ISO)) are becoming increasingly important in this respect (Van Koppen \& Hagelaar, 1998).

Furthermore, it is assumed in ecological modernization theory that monitoring is followed by 'monetarization'. In Huber's (1985) terms, 'ecologizing of the economy' goes hand in hand with the 'economizing of ecology'. There must be a price attached to the use of substance flows. ${ }^{1}$

J. Environ. Policy Plann. 2: 323-335 (2000) 
The relation between economic and ecological rationalities must be explored more precisely, ecological modernization theory argues that the independent set of ecological criteria should be used alongside other, existing economic criteria in order to adequately judge the productivity or performance of industries and technologies. In this respect, ecological modernization theory does not argue for ecological criteria to be used as absolutist, ultimate or sine qua non criteria, as some environmentalist (Bartlett, 1986; Dryzek, 1987) or human ecologists (Odum, 1969; Fischer-Kowalski, 1997) would have it. As Huber (1991) reminds us, one should not forget that-when introducing ecobalancing and annual reports on environmental performances within companies, or in the case of ISO environmental norms and different forms of ecobenchmarking-economic parameters remain crucial for the overall survival of the company. However, this 'relative independency' argument also works the other way around: when talking about economic aspects of sustainability, one should not exclude from the discussion all the issues that - if measured in 'classical' economic terms - could somehow sometimes be of potential harm to the company.

So much for the ecological modernization approach as a general theory of environmentinduced social change. It will be evident that the overall approach described thus far transcends and cross-cuts some of the disciplinary boundaries upheld in the present academic world. Without embracing a full-blown interdisciplinary perspective, ecological modernization theory can profit from specific inputs from technical, economic and social science disciplines. At least at the international level, it can be observed that some connections are developing between research groups, and that it is recognized that multidisciplinary work is becoming something of a rule, instead of the exception, within the 'factor four' tradition. ${ }^{2}$ Sociologists can and should make a specific contribution to this broader research field by focusing on two basic aspects that are not fully and automatically recognized within other disciplines.

First, the importance of the role of human agency in bringing about more sustainable production and consumption arrangements. When studying production-consumption cycles, sociologists should not lose sight of human agency, particularly within dematerialization projects, where human agency runs the risk of disappearing in large data sets and holistic system-theoretical modelling. All productionconsumption cycles consist of social practices that can and should be studied at two levels ('micro' and 'macro'), without accepting a micro-macro division of labour that would draw very rigid dividing lines between the two approaches. When dealing with this issue at the conceptual level, the structurationist argument of the duality of structure (Giddens, 1984) still appears to be the most valid solution to the micro-macro divide (an issue returned to later).

Second, sociologists should stress the need for a re-evaluation of production-consumption arrangements from a consumer-led perspective. For a long time, environmental sociology shared a productivist orientation to the study of industrial society with most social sciences. More recently, the 'post-Fordist turn' has established a perspective that recognizes the crucial position of consumers and consumer groups in structuring production-consumption cycles under the condition of (late or reflexive) modernity. The concept of consumer society is, therefore, no longer seen as a starting point for merely criticizing overconsumption, but it is recognized instead as the key concept to a better understanding of the dynamics of industrial societies.

By elaborating on these two general questions, environmental sociologists can contribute to shaping and improving environmental policies related to different target groups. The socalled 'target group approach' - described, for example, in the Dutch National Environmental Policy Plans (VROM, 1989, 1994)_implies the recognition that society can no longer be 'regulated' in a uniform way from one centre or central government; instead, it should take into account more horizontal ways of policy-making, in which target groups actively take part in the self-steering towards sustainability. On the other hand, target groups were initially selected with reference to their environmental performance only, without taking into account the very different social dynamics that exist between and within these groups. In this way, it

J. Environ. Policy Plann. 2: 323-335 (2000) 
has taken a long time for policy-makers to recognize that consumers are very different from producers, retailers or farmers, not only with respect to their environmental characteristics and dynamics, but also in terms of the social characteristics 'behind' their environmental performance.

The different social roles and institutions connected to the different target groups require an approach that is not only different with respect to the environmental policy targets set or the instruments chosen. They also demand a theory of environment-induced social change that takes these broader social dynamics into account at the conceptual level. Put rather simply, there is not one factor four (or ten) or one dematerialization route with an accompanying theory, but there are many routes with various sets of social actors, and involving different social mechanisms. At a general level, crucial principles such as 'monitoring of substance flows', and the subsequent need for a 'monetarization of these flows' remain valid. However, the concrete forms through which this can be achieved vary for different target groups, and within different geographical configurations. We can and should focus on these 'middle-range levels' when further developing ecological modernization theory for the future.

\section{A consumer-led perspective on ecological modernization: the example of domestic consumption}

It can be argued that home-based social practices or domestic routines are an important issue for environmental scientists, because it is here that our 'relationship with the sustenance base', our daily interaction with nature on a routine basis, is shaped to a considerable extent. The basic approach put forward by ecological modernization theory to the study of domestic consumption will be outlined in this section (for more details, see Spaargaren \& Van Vliet, 2000). Figure 2 visualizes the basic principles of our consumption approach. ${ }^{3}$

The socio-technical innovations developed to enable the greening of (domestic) consumption

HUMAN AGENT - . . . . . . . . . SOCIAL PRACTICES - . . . . . . STRUCTURES

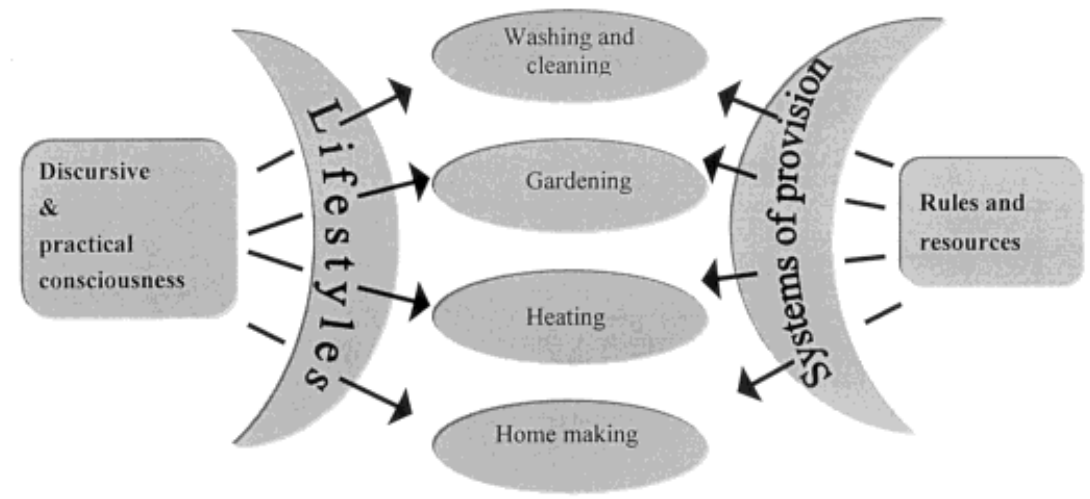

CCC LEVELS - . . . . . . . . DOMESTIC ROUTINES - . . . . . . CSMS

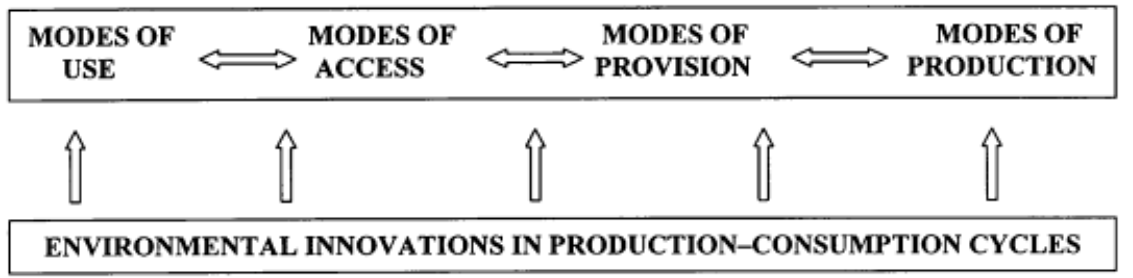

Figure 2. Conceptual model for analysing the ecological modernization of domestic consumption. 
are outlined in the bottom half of Figure 2. The design, development, diffusion and (non)adoption of these (environmental) innovations are among the central objects of study in the sociology of technology. There, it is argued that one should always take into account the historical context of origin of the new products and devices that are or should be used by householders to green their domestic practices. Green products and services are not just there, and they do not drop out of thin air. They are embedded in socio-technical networks that embrace specific groups of producers, retailers, consumers and numerous other relevant actors in the (food supply) chain or (energy) sector under study. To understand why, how and to what extent domestic routines incorporate the new equipment, products, goods or (utility) services, one has to study the ways in which these socio-technical devices are produced, made available, acquired and used by different actor groups in the chains or cycles of production and consumption. The sociology of technology offers a lot of valuable insights here, by looking at the dynamics of the chain at different phases of the process. When studying the modes of production, provision, access and use of the products and services that are used by domestic agents to pursue more sustainable domestic routines, one can avoid most of the pitfalls of, for example, those (economic) perspectives on consumption that focus almost exclusively on single products, made available and acquired primarily in the market mode of consumption (Douglas \& Isherwood, 1979).

Thus, the bottom half of Figure 2 indicates the fact that socio-technical innovations, studied from the perspective of the sociology of technology, are an important element in the analysis of the ecological modernization of domestic consumption. However, this should be taken further. Within the sociology of technology, the notion of human agency has been developed only to a limited extent (Cowan, 1983; Schot, 1992). When it comes to analysing the reasons or motives of human actors for refusing or adopting certain socio-technical devices, the floor is usually left to social psychologists, who dominated environmental sociology for a considerable period of time (for a

Copyright (C) 2000 John Wiley \& Sons, Ltd. more elaborate discussion, see Spaargaren, 1997b, chapters 5-6). This resulted and, to some degree, still results in a division of labour that reproduces the classical divide between individuals and socio-technical networks, between actors and structure. To avoid this dualism, the top half of Figure 2 was designed in visualizing the way in which human agency can be given a central place in the analyses of domestic consumption without lapsing into either an exclusively subjectivist or a predominant objectivist account of domestic consumption. Following the arguments and concepts put forward by Giddens (1984) in his work on the structuration theory, we conceive of domestic routines as social practices implicated in the duality of structure.

The notion of the duality of structure should be 'handled' in practical research by working with two types of perspectives on the very same sets of social practices: the perspective of strategic conduct, on the one hand, and that of institutional analysis on the other. When working from the perspective of strategic conduct, the focus is on the reasons and motives of agents, their life-styles as connected to 'narratives' of the self, or statements of self-identity. This actor-centred perspective emphasizes the fact that however pervasive and immobile some social structures or institutions seem to be, they are always produced and reproduced by knowledgeable and capable human agents who are able to provide comments, reasons and even some explanation for what they are doing and how they are doing it. The general principle of treating people as accountable human agents is also particularly relevant to issues of 'green lifestyles' and sustainable consumption patterns. Moreover, we would argue that the concept of life-style has an important role to play in the study of the 'greening of consumption' as strategic conduct. In this sense, life-style is embraced as a fruitful alternative to the psychological concept of 'attitude', ${ }^{4}$ rather than being rejected as a vague concept as some authors would prefer. The reported vagueness or 'multiple definition question' that would come along with the life-style concept surrounds-we would argue-all of the core concepts of sociology (such as, for example, the concepts of power,

J. Environ. Policy Plann. 2: 323-335 (2000) 
agency, time and ideology). The only solution to this problem is to make explicit one's theoretical perspective and to provide, within this specific theoretical framework, a concrete and consistent definition of the life-style concept. The definition of the life-style concept within structuration theory runs as follows: 'A lifestyle can be defined as a more or less integrated set of practices which an individual embraces, not only because such practices fulfil utilitarian needs, but because they give material form to a particular narrative of the self' (Giddens, 1991, p. 81). Part of this 'narrative' in the context of domestic consumption will be the level of comfort, cleanliness and convenience (CCC) (see Shove, 1997) one is accustomed to.

Taking the motives and interest of human agents seriously does not have to imply that, as a result of a 'mode of strategic conduct' analysis, we would forget about the fact that actors are not isolated 'single units' or individuals, but always co-actors or co-civilians. The embeddedness of social action is taken as the primary point of departure when taking on board an institutional perspective on domestic (consumption) routines. Using this perspective or 'mode of analysis', we focus on the rules and resources underlying domestic practices. In other words (again borrowing from the sociology of consumption), we are looking at ways in which these rules and resources are structuring the systems of provision implied in the consumption practices under study (Fine \& Leopold, 1993). With respect to domestic consumption, Otnes (1988), a Norwegian sociologist who took on board some of Giddens' basic notions, refers to these systems of provision in terms of the collective socio-material systems (CSMS) (see Figure 2) that are involved in the process of 'serving and being served' in everyday life. These systems-tap-water system, electricity grid, heating infrastructure, sewage system etc-are an essential part of the sustenance base, as they are crucial to the material underpinning of our everyday lives.

Theoretically, the argument is that domestic consumption can and should be studied within both modalities or modes of analysis, without creating a division between the 'micro' and 'macro' or between 'actor' and 'structure'. Taking

Copyright (C) 2000 John Wiley \& Sons, Ltd. domestic consumption as a focus also implies developing a consumer-oriented perspective on the ecological modernization of production and consumption. Empirically we are confrontedat least in a number of European countrieswith a process of ecological modernization that is mirrored in a myriad of dark-green en lightgreen life-styles and domestic environmental arrangements, with different and diversifying modes of production, provision, access and use. To illustrate the use of the model as an analytical tool for empirical research, we will shortly discuss the EU-funded research project DOMUS as an illustration (Chappells et al., 2000).

\section{Intermezzo: empirical research on ecological modernization of domestic consumption in some European countries}

The central object of the DOMUS research project (Spaargaren, 1997a, Van Vliet, 1998) was to provide a theoretically meaningful description of the ways in which consumers are involved in the ecological modernization of domestic arrangements for dealing with water, energy and waste. It goes without saying that these arrangements represent, for environmental scientists, a very important potential for the greening of modern industrial life-styles. The expert systems involved in the provision of energy, water and waste are regarded as crucial target groups for environmental policy-making. Finally, there are some sectors of modern society that are going through a period of massive and profound transformations caught in catchwords such as liberalization, privatization or third-party access (TPA); transformations that also stretch beyond the reach of national (governmental) actors, and are, to a considerable extent, influenced by EU policies.

Of course, issues such as (the saving of) energy, water and (the prevention of) waste are central subjects in a lot of (social science) research. Hence, it was not too difficult to collect empirical examples of innovations in the three countries under study: Sweden, the UK and the Netherlands. An inventory was made of

J. Environ. Policy Plann. 2: 323-335 (2000) 
environmental innovations (in the technical and the social sense) that were carried out, implemented or piloted at the grass-roots level, in addition to those of official agencies or expert systems (Raman et al., 1998; Van Vliet et al., 2000). The difficult part of the research, however, was the fact that environmental innovations in these areas are framed in a predominantly technical language, which has a strong bias towards environmental performance in a restricted sense. Devices are discussed mainly with respect to the changes they can bring to energy and material flows, without much reference to the social practices they help to perform. Also, the inventory showed that little attention is given to consumers and consumer involvement in any case. Experts produce and provide green technical devices without much anticipation or reflection on the conditions of access and use as relevant to users/ consumers. While everyone is very much aware, at a general level, of the 'new dynamics' within the energy, water and waste-sectors, and there seems to be a general agreement on the growing strategic importance of good relationships with consumers, this general scheme is not often projected on actual green innovations.

The DOMUS project tried to make a contribution in this respect by illustrating the fact that one can also witness profound changes in the overall relationships between providers and consumers when dealing with green innovations. Changes that pertain to all the dimensions of the process, from production to provision to access to use (see Figure 2) and vice versa. Now that the 'old networks of provision' have gone and are fragmented and under reconstruction (Guy \& Marvin, 1996), the possibilities for experimenting with new (power) relations are abundant. The ecological modernization of domestic routines and concomitant systems of provision is not just a technical affair, or something to be left in the hands of technical engineers, it is a thoroughly social and political process. The so-called Green Electricity Schemes are a case in point. They are available in all possible technical and institutional variants one can think of. The DOMUS project was able to illustrate the fact that the very same (for example, photovoltaic (PV) electricity) technologies can be applied in profoundly different ways when it comes to the modes of access and use from the side of the consumers (Van Vliet et al., 2000). ${ }^{5}$ However, the (political) choices accompanying green technologies seem to be hardly recognized or given proper attention by providers.

\section{The (sub)politics of domestic consumption}

The basic neglect of the crucial role of citizenconsumers in utility sector-related environmental innovations pertains to the sociological literature too. In sociology, home is the place where families are based and reproduced. When long-term changes in domestic routines are the object of study within sociology or anthropology, the focus is on changing power relations between family members, and on new divisions of labour between families and the outside world (e.g. Cowan, 1983). The long-term changes in the material underpinnings of everyday life are only incidentally discussed, and hardly ever investigated empirically from an environmental point of view (Otnes, 1988). Moreover, in the sociological literature concerning citizenship participation in policy-making, the category of utility-sector consumers-as a particular type of (more or less captivated) consumers - is also lacking.

In trying to make up for this lack of attention, we propose, in the DOMUS project, to discuss consumer involvement in two respects, using different bodies of literature in the social sciences. First, one can rethink consumer involvement in terms of 'in-use involvement', referring to the different modes of access and use of socio-technical arrangements that govern the use of energy, water and waste within domestic routines. Second, when abstracting from her or his individual arrangements, citizen-consumers can become involved in the production and provision of household-related socio-technical innovations within the (sub)political domain, to be referred to as '(sub)political involvement'. With this analytical distinction in mind, we are better able to discuss the politics of domestic consumption in all its major dimensions.

J. Environ. Policy Plann. 2: 323-335 (2000) 
In-use involvement refers to involvement in the functioning of the socio-material collective systems. Here, we can benefit from some of the notions of the sociology of science and technology, especially as developed by Cowan (1983), Callon et al. (1986), Cramer \& Schot (1990) and Schot (1992). The DOMUS project provides some excellent empirical examples of very similar technological systems being organized with and without consumer involvement. This raises questions regarding the forms and the appropriate levels of consumer involvement that people actually want when they become engaged in the process of the greening of their life-styles and domestic consumption. In dealing with these questions in some detail, we should move away from old questions regarding the 'acceptance of innovation', such as the one-dimensional question of 'how much money do they want to pay for it?'. By being more precise about both the (material, social and cultural) efforts and rewards that come along with certain innovations, the (perceived) consequences of the innovations for the different segments of the life-style, and the potential effects of the innovation on (sub)culturally accepted levels of comfort, convenience and cleanliness (Shove, 1997), a more sophisticated theory can be developed with regard to the ecological modernization process in this specific domain of social life, resulting in more sustainable systems of provision and informing upon more sustainable life-styles for domestic agents. In the DOMUS project, we encountered cases that actually represented different models of in-use involvement. Sometimes people developed bottom-up forms of (greener) self-provision, which were aimed at gaining autonomy vis-à-vis the big utility companies, bringing rather intensive efforts from citizenconsumers themselves along with them. In other cases, environmental innovations took the form of consumer groups opting for forms of co-provision, in which both the utility providers and the domestic consumers took their (more or less equal) share. Finally, there are consumers who primarily want to be 'served', even when more sustainable arrangements are at stake. This is illustrated in the great variety of green electricity schemes offered to domestic consumers by utility companies in several European countries. ${ }^{6}$
Most of these schemes do not change anything with respect to the hardware of energy provision at the domestic level. Consumers are just asked to apply for the green scheme, and pay some extra money for it. Providers guarantee that somewhere in the energy infrastructure an amount of green energy will be generated that equals the electricity consumption of the householders. A reliable third party (for example Worldwide Fund for Nature or Friends of the Earth) can see to it that the green promises made by companies to householders are actually met (Spaargaren, 1999).

Second, life-style is not just an individual affair and citizenship involvement pertains also to the ways in which people become engaged, not just with their own energy-, water- and waste-handling devices and arrangements, but with the subpolitics of domestic consumption. Citizens might become involved in the ways in which domestically relevant environmental arrangements are developed by experts in water, energy and waste companies (utility sectors), on the one hand, and experts within municipal and central governments on the other. With respect to this mode of influencing broader processes of policy-making, it can be argued that some of the traditional institutions for policy-making have become obsolete (see also Offe, 1986; Beck, 1992; Beck et al., 1994; Giddens, 1998). In this period of reflexive modernity, we should indeed opt for new kinds of arrangements and involvements that Beck and Giddens refer to as subpolitics. Political engagement that does not stop at the classical repertoire of voting, protesting and boycotting, but takes into account forms of co-production and co-provision of energy, water and waste arrangements at different scales in time and space, from the individual home to the neighbourhood, the national level and beyond. In the DOMUS project, the subpolitics of domestic consumption was found to be less developed than the debate on in-use involvement. In dealing with environmental movements and grass-roots initiatives too, the debate on energy, water and waste seems to be dominated by technical and economic aspects. The potentials or dangers for the ecological modernization of domestic consumption stemming from the overall processes of 
privatization and liberalization are only beginning to be discussed (Chappells et al., 2000).

When exploring the future involvement of citizen-consumers in the systems of provision that form the material underpinnings of domestic consumption along these lines, we run (again) into questions that have occupied environmental sociologists for a long time.

- Is small (still/again) the most sustainable? As a result of technological developments and changing attitudes of expert systems, there seem to be greater possibilities for 'decentralized' systems, (re)connected to the central grid in a flexible way. These technological developments are closely related to changing power relations between producers and consumers. One of the more interesting aspects of these changing relationships between the decentralized and the central is the question whether the Schumacher (1973) adage 'small is beautiful' can be reformulated in a way that fits the socio-technical networks that are characteristic of reflexive modernity.

- Do environmental innovations at the domestic level allow for or contribute to new forms of solidarity, or even communitarianism? In the debate on the limits to privatization or individualization, some philosophers argue that new forms of subpolitics should also be assessed with respect to the contribution they can make to new forms of solidarity that could accompany new environmental arrangements. With utility infrastructures 'moving away' from their end-users by being organized and managed at increasing levels of scale, the same technologies allow for new forms of subpolitical arrangements that might give the block or neighbourhood a new, present-day (materially visible) identity.

These old questions deserve present-day treatment. Formerly, in the context of the debates on demodernization, the answers almost automatically followed from a general retreat of modern society. Sustainable domestic provision was identical to self-provision in local units that were 'off grid', both in the technical and social dimension. Now that the opt-out solution is no

Copyright (C) 2000 John Wiley \& Sons, Ltd. longer regarded as a feasible strategy, and green(er) arrangements are available in all possible social and technical forms, we should come up with new answers. If used as input to a political debate on sustainable consumption under the condition of reflexive modernity, this search for new answers will perhaps inspire lots of citizen-consumers to actively partake in that exercise.

\section{Notes}

1. In this respect, ecological modernization theory resembles the notion of 'internalization of external costs' used by many environmental economists. For an early formulation of this thesis, see Hueting (1974).

2. Among the numerous examples available, we just mention the Wuppertal Institute and their work on ecological footprints, the 'industrial metabolism group' around Marina FischerKowalski, the EAWAG-institute in Zürich and the Refine project coordinated by Wageningen University.

3. The fact that domestic consumption is taken as a specific type of social practice (Warde, 1990) does not mean that we hold these domestic practices to be the only or single most relevant category for the sociology of consumption. The concepts of sustainable consumption and sustainable life-styles are more embracing categories, as not all consumption practices are best explained or investigated from a home-bound perspective. In theoretical terms, the time-space organization of everyday life is essentially, though not exclusively, connected to the home as locale or physical setting of consumption. For example, the production-consumption cycles in the food industry (with a specific role for retailers) cannot be investigated solely from a domestic consumption perspective. This is because they are not only connected to the home-bound practices of storing food and preparing meals, they also imply complementary roles of consumers as shoppers, dreamers, air-miles or bonus-point savers etc.

4. In the so-called attitude-behaviour paradigm, which was developed especially from the work of Fishbein \& Ajzen (1975), attitudes serve as the most important predictor of (consumption) behaviour.

5. Green electricity can be bought from utility companies or from the environmental movement ${ }_{i}$ it

J. Environ. Policy Plann. 2: 323-335 (2000) 
can be applied at the level of the individual home, the block or the neighbourhood; it can be applied 'stand-alone' or 'grid connected', or a combination of the two; it can be used 'hidden away' or highly visible etc.

6. Cases in point are the experiments with PV technologies, as applied in the built environment. First, in some cases, people are developing their own, integrated sustainable homes in the form of bottom-up housing projects initiated by groups of future inhabitants of the sustainable homes. Here, PV technologies are used in combination with other environmental innovations (decentralized sanitation systems, windmills and so on), in order to become selfsufficient in energy and water consumption. Delinking from existing utility infrastructureswhich are judged to be offering only limited possibilities for green householding - is one of the driving motives of the future inhabitants. Second, there are cases where sustainable options are not defined in terms of grid autonomy, but instead forms of co-provision between utility-providers and local consumers are striven for. Here, the PV technologies are either bought or rented from the utility companies, which also perform the installation and maintenance of the system. Domestic consumers make use of their own 'green' electricity when performing tasks within the households, and they only use the central grid as a guard network. A double metering system keeps the householders informed about their level of self-sufficiency vis$\grave{a}$-vis their reliance on the central grid. Finally, projects are developed by utility companies in coordination with local authorities, and building agencies where PV technologies are attached to the roofs of all the houses in the area (both private ownership and rental houses), without even consulting (future) inhabitants about this. The electricity generated by these systems is plugged into the central grid without any form of monitoring at the decentralized level. Householders use the central grid just like every one else, finding comfort from the idea that their houses make an active contribution to the greening of the central grid. It goes without saying that the three forms of application of PV technology all offer different possibilities for householders to become 'involved' in the provision of energy at the local level, both in the technical sense and with respect to their chances of displaying green life-styles (Spaargaren, 1999).

Copyright (C) 2000 John Wiley \& Sons, Ltd.

\section{References}

Bartlett RV. 1986. Ecological rationality: reason and environmental policy. Environmental Ethics 8: 221239.

Beck U. 1992. From industrial society to the risk society: questions of survival, social structure and ecological enlightenment. Theory, Culture \& Society 9: $97-123$

Beck U, Giddens A, Lash S. 1994. Reflexive Modernisation: Politics, Tradition and Aesthetics in the Modern Social Order. Polity Press: Cambridge.

Blühdorn I. 2000. Ecological modernization and post-ecologist politics. In Environment and Global Modernity, Spaargaren G, Mol APJ, Buttel FH (eds). Sage Publications: London; 209-229.

Buttel FH. 2000. Ecological modernization as social theory. Geoforum 31: 57-65.

Callon M, Law J, Rip A (eds). 1986. Mapping the Dynamics of Science and Tecbnology: Sociology of Science in the Real World. Macmillan: Basingstoke.

Chappells H, Klintman M, Linden A-L, Shove E, Spaargaren G, van Vliet B. 2000. Domestic Consumption, Utility Services and the Environment: Final Domus Report. Wageningen University: Wageningen.

Cowan RS. 1983. More Work for Mothers. Basic Books: New York, NY.

Cramer J, Schot J. 1990. Problemen rond innovatie en diffusie van milieutechnologie. Een onderzoeksprogrammeringsstudie verricht vanuit een technologiedynamica perspectief. Raad voor het Milieu- en Natuuronderzoek: Rijswijk.

Douglas M, Isherwood B. 1979. The World of Goods: Towards an Antbropology of Consumption. Allen Lane: London.

Dryzek JS. 1987. Rational Ecology: Environment and Political Economy. Basil Blackwell: Oxford.

Fischer-Kowalski M. 1997. Society's metabolism: on childhood and adolescence of a rising conceptual star. In International Handbook of Environmental Sociology, Redclift M, Woodgate G (eds). Edward Elgar Publications: Cheltenham, 119-137.

Fine B, Leopold E. 1993. The World of Consumption. Routledge: London.

Fishbein M, Ajzen I. 1975. Belief, Attitude, Intention, and Behavior. Addison-Wesley: Reading, MA.

Giddens A. 1984. The Constitution of Society: Outline of the Theory of Structuration. Polity Press: Cambridge.

Giddens A. 1990. The Consequences of Modernity. Polity Press: Cambridge.

Giddens A. 1991. Modernity and Self-Identity: Self and Society in the Late Modern Age. Polity Press: Cambridge.

J. Environ. Policy Plann. 2: 323-335 (2000) 
Giddens A. 1998. The Third Way: The Renewal of Social Democracy. Polity Press: Cambridge.

Guy SC, Marvin SJ. 1996. Transforming urban infrastructure provision - the emerging logic of demand side management. Policy Studies 17: 137-147.

Hannigan JA. 1995. Environmental Sociology: A Social Constructionist Perspective. Routledge: London.

Huber J. 1982. Die verlorene Unscbuld der Ökologie: Neue Technologien und superindustrielle Entwicklung. Fisher Verlag: Frankfurt am Main.

Huber J. 1985. Die Regenbogengesellschaft: Ökologie und Sozialpolitik. Fisher Verlag: Frankfurt am Main.

Huber J. 1991. Ecologische modernisering: weg van schaarste, soberheid en bureaucratie? In Technologie en milieubebeer: Tussen sanering en ecologische modernisering, Mol APJ, Spaargaren G, Klapwijk A (eds). Den Haag: SDU Uitgeverij ${ }_{i}$ 167-185.

Hueting R. 1974. Nienwe schaarste en economische groei. Agon Elsevier: Amsterdam.

Koppen CSA van, Hagelaar JLF. 1998. Milieuzorg als strategische keuze. Van bedrijfsspecifieke situatie naar milieuzorgsystematiek. Bedrijfskunde 70(1): 45-51.

Martell L. 1994. Ecology and Society: An Introduction. Polity Press: Cambridge.

Mol APJ, Spaargaren G. 2000. Ecological modernisation theory in debate: a review. In Ecological Modernisation around the World: Perspectives and Critical Debates, Mol APJ, Sonnenfeld DA (eds). Frank Cass: London; $17-50$.

Odum EP. 1969. The strategy of ecosystem development. Science 164: 262-270.

Offe C. 1986. Nieuwe sociale bewegingen als metapolitieke uitdaging. In Tegenspraken, dilemma's en impasses van de verzorgingsstaat: SOMSO Staatsdebat, Inleiding, Maesen LJG van der, Kuypers P (eds). Stichting Onderzoek Maatschappelijke Strategie Ontwikkeling: Amsterdam, 27-92.

Otnes P. 1988. Housing consumption: collective systems service. In The Sociology of Consumption: An Anthology, Otnes P (ed.). Humanities Press: Atlantic Highlands, $\mathrm{NJ}_{i}, 119-138$.

Pellow DN, Schnaiberg A, Weinberg AS. 2000. Putting the ecological modernisation thesis to the test: the promises and performances of urban recycling. In Ecological Modernisation around the World: Perspectives and Critical Debates, Mol APJ, Sonnenfeld DA (eds). Frank Cass: London, 109-138.

Raman S, Chappells H, Klintmann M, Vliet B van. 1998. Inventory of Environmental Innovations in Domestic Utilities: The Netherlands, Britain \& Sweden. Wageningen University: Wageningen.

Copyright (C) 2000 John Wiley \& Sons, Ltd.
Schnaiberg A. 1980. The Environment: From Surplus to Scarcity. Oxford University Press: Oxford.

Schot J. 1992. Constructive technology assessment and technology dynamics: the case of clean technologies. Science, Tecbnology and Human Values 17(1): $36-56$.

Schumacher EF. 1973. Small is Beautiful: A Study of Economics as if People Mattered. Blond \& Briggs: London.

Shove E. 1997. Notes on comfort, cleanliness and convenience. Paper for the ESF workshop on Consumption, Everyday Life and Sustainability. Lancaster, 5-8 April.

Spaargaren G. 1997a. Citizenship involvement in the ecological modernisation of household-related public utility sectors in the EU. From captive to authoritative consumer. Research proposal for the EU programme 'Environment and Climate 19941998', no. PL970850.

Spaargaren G. 1997b. The ecological modernization of production and consumption: essays in environmental sociology. PhD thesis, Wageningen Agricultural University.

Spaargaren G. 1999. Case-study duurzame energie. In Verklaringen van duurzame consumptie: Een speurtocbt naar nieuwe aanknopingspunten voor milieubeleid, Beckers $T$, Ester $\mathrm{P}$, Spaargaren G (eds). Ministerie van VROM, DG milieubeheer: Den Haag, 63-71.

Spaargaren G. 2000. Ecological modernization theory and the changing discourse on environment and modernity. In Environment and Global Modernity, Spaargaren G, Mol APJ, Buttel FH (eds). Sage Publications: London; 41-73.

Spaargaren G, Mol APJ, Buttel FH. 2000. Introduction: globalization, modernity and the environment. In Environment and Global Modernity, Spaargaren G, Mol APJ, Buttel FH (eds). Sage Publications: London; $1-16$.

Spaargaren G, Vliet B van. 2000. Lifestyles, consumption and the environment: the ecological modernisation of domestic consumption. In Ecological Modernisation around the World: Perspectives and Critical Debates, Mol APJ, Sonnenfeld DA (eds). Frank Cass: London, 50-77.

Ullrich O. 1979. Weltniveau: In der Sackgasse der Industriegesellschaft. Rotbuch Verlag: Berlin.

Vliet B van. 1998. Analysing Environmental Change in the Relations between Utility Sectors and Domestic Consumers. Wageningen Agricultural University: Wageningen. Vliet B van, Wüstenhagen R, Chappells H. 2000. New provider-consumer relations in electricity provision. Green electricity schemes in the UK, the Netherlands, Switzerland and Germany. Paper for the Business Strategy and the Environment Conference, Leeds, 18-19 September.

J. Environ. Policy Plann. 2: 323-335 (2000) 
VROM (Ministry of Housing, Regional Development and the Environment, Netherlands Ministry of Economic Affairs; Ministry of Agriculture, Nature Management and Fisheries; Ministry of Transport, Public Works and Water Management). 1989. National Environmental Policy Plan: To Choose or Lose. SDU uitgeverij: 's-Gravenhage.

VROM (Ministry of Housing, Regional Development and the Environment ${ }_{i}$ Netherlands Ministry of Economic Affairs; Ministry of Agriculture,
Nature Management and Fisheries; Ministry of Transport, Public Works and Water Management). 1994. National Environmental Policy Plan 2: Today's Touchstone. SDU uitgeverij: 'sGravenhage.

Warde A. 1990. Introduction to the sociology of consumption. Sociology 24: 1-4.

Yearley S. 1991. The Green Case: A Sociology of Environmental Issues, Arguments and Politics. Harper Collins Academic: London. 